\title{
THE TRANSLATION QUALITY OF FACEBOOK TRANSLATION
}

\author{
Arif Nurul Hakim¹, Andi Dian Rahmawan² \\ ${ }^{1,2}$ Department of English Language Education, Universitas PGRI Yogyakarta \\ Corresponding Author(S): sevenribs14@gmail.com
}

\begin{abstract}
:
This study aims to assess the quality level of the Facebook translation From English to Indonesian, what techniques are used and to determine the causes of the low quality of the automatic translation tool. This study compares the results of the Facebook translation with the results of the respondents presented with a qualitative descriptive method. The researcher conducted a test on 40 Facebook translation data involving 8 students of the English language education study program to assess whether the Facebook translation results were acceptable or still require re-translation from them. From 48 techniques used by Facebook, found 48 data $(100 \%)$ categorized as not accurate, not acceptable and low readability translations consisting of 37 data using literal translation $(77,1 \%)$, borrowing namely 9 data $(18,7 \%)$, calque namely 1 data $(2,1 \%)$, and reduction namely 1 data $(2,1 \%)$. Meanwhile, the translation techniques used by the respondents were more diverse. From 54 techniques used by Respondents, found 54 data (100\%) categorized as accurate, acceptable and high readability translations consisting of 21 data using literal translation $(38,8 \%)$, adaptation namely 14 data $(25,9$ $\%)$, transposition namely 9 data $(16,6 \%)$, borrowing namely 4 data $(7,4 \%)$, description namely 2 data $(3,7 \%)$, amplification namely 1 data $(1,9 \%)$, calque namely 1 data $(1,9 \%)$, modulation namely 1 data $(1,9 \%)$ and reduction namely 1 data $(1,9 \%)$. Facebook's tendency to often use Literal translation is believed to be the cause of the low level of quality because this technique is used as an early stage of translation and is called the lowest technique.
\end{abstract}

Keywords:

Facebook, translation, translation technique.

\section{INTRODUCTION}

Today, Social media plays an important role in disseminating news and information, this is evidenced by the emergence of accounts belonging to news portals and official government agencies to make it easier to reach everyone. But again, information from the outside world is always conveyed in English and also applies to social media. In this case, Facebook as the focus of this research is one of the popular social media among netizens around the world with several advantages such as Fanpage and Group features that can accommodate multiple accounts to resonate as a means of socializing and exchanging information and buying and selling. 
Recently Facebook added an automatic translation feature that can translate dozens of languages around the world through a 'view translation' feature which can be adjusted by the user. Like other online translators, Facebook translation also works using artificial intelligence, which is prone to errors, as the author found in a post that said "cat in labor drags hooman to her nest." translates to "Kucing di buruh menyeret hooman ke sarangnya." this certainly cannot represent the message conveyed from the source language to the target language where 'labor' in this case is literally translated as 'buruh' or in other words is factory worker which should be translated into 'maternity or childbirth' which is indeed the word English for maternity and labor are both "labor". It is clear here that the Facebook translation is not correct in identifying contextually to translate the word 'labor' into the target language, namely Indonesian. Also, the word hooman here translates into pure borrowing as "hooman" which is the slang word for "human" or human in this case the owner of a cat. From these findings, it can be seen that from just one simple sentence there are two aspects of translation errors.

From the description above, the writer conducted research on the translation results of Facebook, which is expected to be able to find out the quality of the translation results of the social media tools, what techniques often appear which in the end result in the translation results tend to be miss-conveyed and confusing. In the end, it can be seen whether the results of the Facebook translation feature can be fully recommended for netizens. On the other hand, it can be a motivation for students studying languages to be able to improve their skills, especially in the field of translation. Likewise for the developer so that it can be a reference for further refining its product to make it better.

\section{METHOD}

The author uses a qualitative descriptive method in this study. Descriptive qualitative research is one of the types of research included in the type of qualitative research. The purpose of this study is to reveal events or facts, circumstances, phenomena, variables and circumstances that occurred during the study by presenting what actually happened (Prasetyo, 2016). This study interprets and describes the data related to the current situation, attitudes and opinions that occur in a society, the conflict between two or more situations, the relationship between variables that arise, the differences between existing facts and their effect on a condition, and so on.

Data obtained from social media Facebook, which departs from the reality in the field that one of the author's friend complained about the translation results on Facebook he could not understand. Starting from that the author and several colleagues began to collect the data. Data from the field is in the form of screenshots, which includes posts from a Facebook account that uploads videos, photos, and status along with a short caption as a support. Previously, the translation feature was activated and set in advance from English to Indonesian so that the original English caption was obtained as the Source Language (SL) and the translation results in Indonesian as the Target Language (TL).By involving several colleagues, including the author taking part in the search for data in the field, it resulted 40 screenshots of data were found. Then the data is processed further so that data is obtained in the form of tables containing images, words, phrases, clauses or sentences. 
Figure 1 Data Screenshot from Facebook

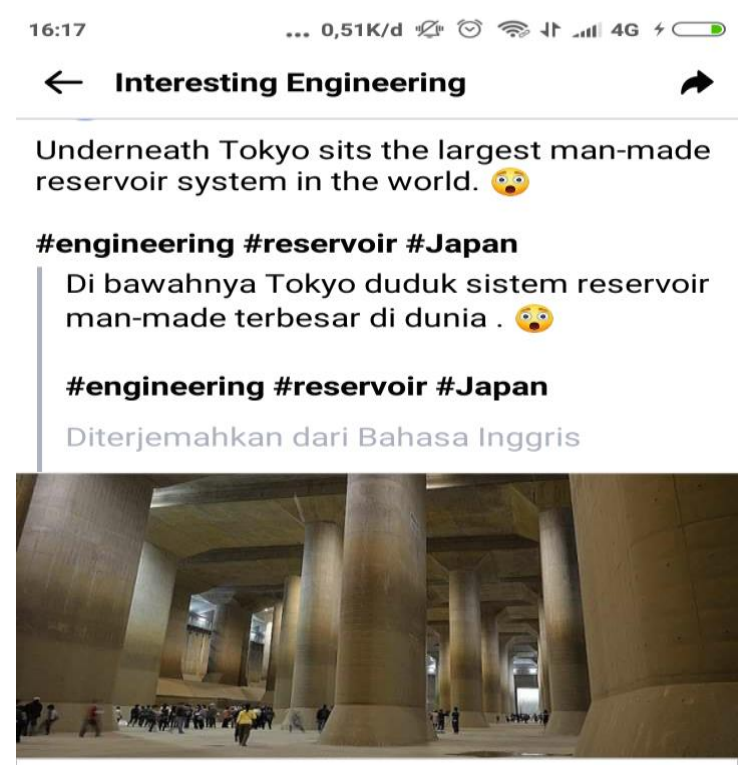

The researcher distributed table 1 to 8 respondents who later on the respondent would analyze the content and translate SL to TL according to their abilities.

Table 1 Instrument

\begin{tabular}{|c|c|c|c|c|}
\hline NO. & $\begin{array}{l}\text { Source } \\
\text { (SL) }\end{array}$ & $\begin{array}{c}\text { Translated by } \\
\text { Facebook } \\
\text { (TL I) }\end{array}$ & $\begin{array}{c}\text { Your } \\
\text { Translation } \\
(\text { TL II) }\end{array}$ & $\begin{array}{c}\text { Translation Technique by } \\
\text { Respondent }\end{array}$ \\
\hline
\end{tabular}

Researchers identified translation techniques based on table 1 instrument. At this stage the researcher used Molina and Albir (2002) theories to determine the translation techniques used. Meanwhile, the assessment process regarding the quality of the translation is carried out using the assessment procedure from Nababan (2012).

\section{RESULTS AND DISCUSSION}

This section will present the translation quality and the percentage of each translation technique used by Facebook and the respondents.

\section{Translation by Facebook}

Table 2 Calculation of Facebook

\begin{tabular}{|c|c|c|c|c|c|c|c|c|c|c|c|c|}
\hline No & Technique & $\mathbf{F}$ & $\%$ & $\mathbf{A}$ & $\mathbf{L A}$ & $\mathbf{N A}$ & $\mathbf{A}$ & LA & NA & $\mathbf{H}$ & $\mathbf{M}$ & $\mathbf{L}$ \\
\hline 1 & Adaptation & & & & & & & & & & & \\
\hline 2 & Amplification & & & & & & & & & & & \\
\hline 3 & Borrowing & 9 & 18,7 & & & 9 & & & 9 & & & 9 \\
\hline 4 & Calque & 1 & 2,1 & & & 1 & & & 1 & & & 1 \\
\hline 5 & Compensation & & & & & & & & & & & \\
\hline 6 & Description & & & & & & & & & & & \\
\hline 7 & Discursive Creation & & & & & & & & & & & \\
\hline
\end{tabular}




\begin{tabular}{|c|c|c|c|c|c|c|}
\hline \multirow{2}{*}{8} & Established & & & & & \\
\hline & Equivalent & & & & & \\
\hline 9 & Generalization & & & & & \\
\hline \multirow{2}{*}{10} & Linguistic & & & & & \\
\hline & Amplification & & & & & \\
\hline 11 & $\begin{array}{l}\text { Linguistic } \\
\text { Compression }\end{array}$ & & & & & \\
\hline 12 & Literal Translation & 37 & 77,1 & 37 & 37 & 37 \\
\hline 13 & Modulation & & & & & \\
\hline 14 & Particularization & & & & & \\
\hline 15 & Reduction & 1 & 2,1 & 1 & 1 & 1 \\
\hline 16 & Substitution & & & & & \\
\hline 17 & Transposition & & & & & \\
\hline 18 & Variation & & & & & \\
\hline \multicolumn{2}{|c|}{ TOTAL } & 48 & 100 & 48 & 48 & 48 \\
\hline \multicolumn{2}{|c|}{ F: Frequency } & & Accep & & & \\
\hline \multicolumn{2}{|c|}{$\%:$ Percentage } & & Less & & & \\
\hline \multicolumn{2}{|c|}{ A: Accurate } & & Not & & & \\
\hline \multicolumn{2}{|c|}{ LA: Less Accurate } & & ligh & & & \\
\hline \multicolumn{2}{|c|}{ NA: Not Accurate } & & Mode & & & \\
\hline
\end{tabular}

\section{Translation by Respondents}

Table 3 Calculation of Respondents

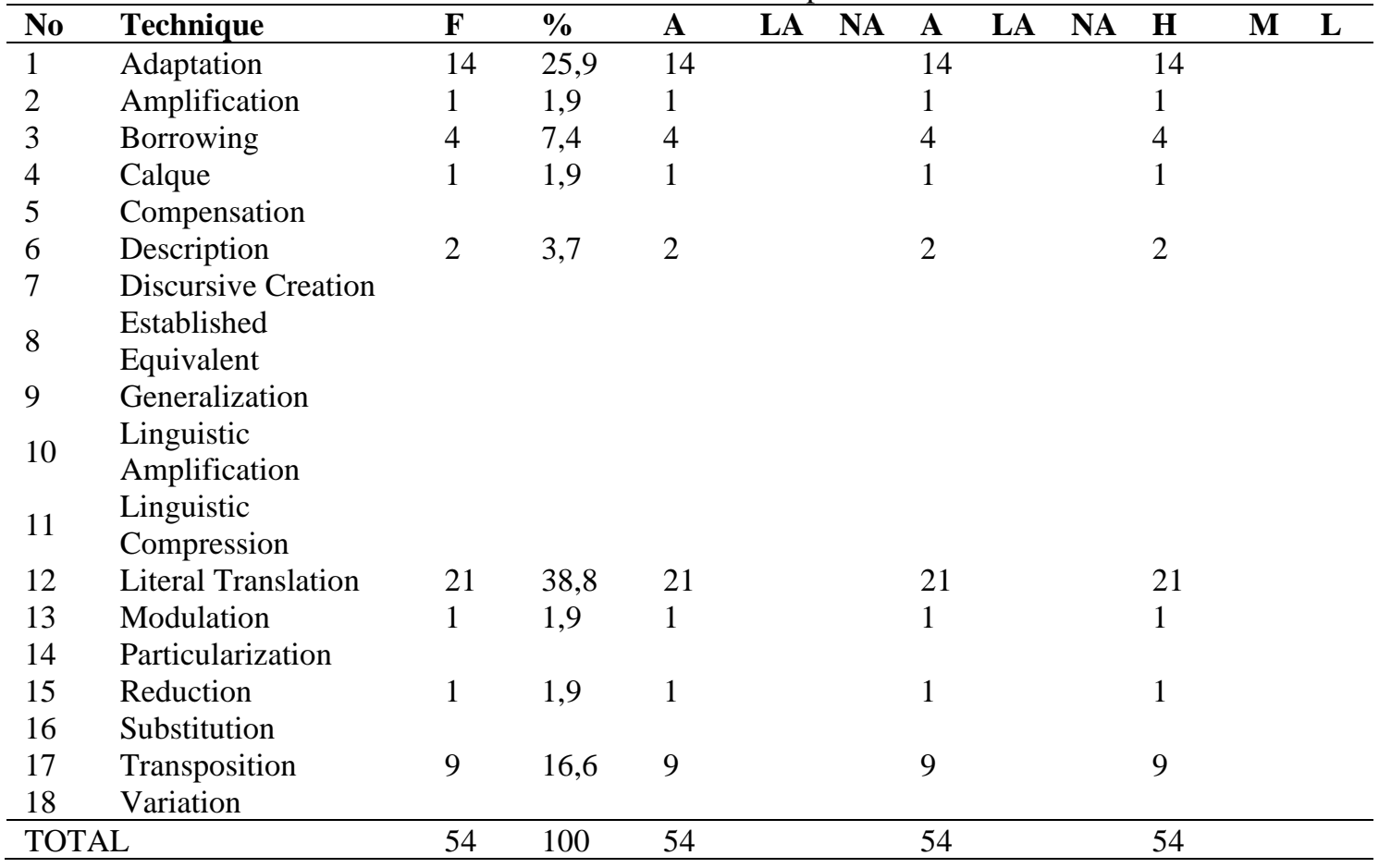

F: Frequency

$\%$ : Percentage

A: Accurate

LA: Less Accurate

NA: Not Accurate

A: Acceptable L: Low

LA: Less Acceptable

NA: Not Acceptable

H: High

M: Moderate 


\section{DISCUSSION}

\section{A. Translation Technique}

Facebook translation technique is dominated by Literal Translation, followed by borrowing, calque and reduction. Meanwhile, the translation techniques used by the respondents were more diverse, namely: literal translation, adaptation, transposition, borrowing, description, amplification, calque, modulation and reduction.

This happens because the respondents realize that the quality of translations provided by Facebook tends to be low. The tendency of Facebook to use literal translation techniques causes the low quality of translation because this technique is used in the early stages of translating and considered as the lowest technique. Meanwhile, most of the 40 data collected are informal texts that tend to use idioms and hyperbolic expressions, of course this phenomenon cannot be addressed using literal translation because there are contextual and cultural aspects that cannot be translated literally. Respondents who in this case can identify the phenomena in the text then retranslate using different and appropriate techniques.

\section{B. Translation Quality}

The translation quality assessment refers to three components: accuracy, acceptability and readability. This evaluation is made by the analysis of the accuracy, acceptability and readability of words and sentences containing translation errors through process of 3 raters. The translation quality assessment proposed by Nababan, Nuraeni and Sumardiono (2012) was used to evaluate the translation quality scale.

\section{Facebook Translation Quality}

From 48 techniques used by Facebook, found 48 data (100\%) categorized as not accurate, not acceptable and low readability translations consisting of 37 data using literal translation $(77,1 \%)$, borrowing namely 9 data $(18,7 \%)$, calque namely 1 data $(2,1 \%)$, and reduction namely 1 data $(2,1 \%)$.

\section{Respondents Translation Quality}

From 54 techniques used by Respondents, found 54 data (100\%) categorized as accurate, acceptable and high readability translations consisting of 21 data using literal translation $(38,8 \%)$, adaptation namely 14 data $(25,9 \%)$, transposition namely 9 data (16,6\%), borrowing namely 4 data $(7,4 \%)$, description namely 2 data $(3,7 \%)$, amplification namely 1 data $(1,9 \%)$, calque namely 1 data $(1,9 \%)$, modulation namely 1 data $(1,9 \%)$ and reduction namely 1 data $(1,9 \%)$.

\section{CONCLUSION}

Analyzing translations from two different translators is an interesting topic. In the following, the researcher draws some conclusions:

1. From the 40 existing data. Only a few translation techniques used by Facebook, namely Literal translation, Borrowing, Calque and Reduction.

2. Facebook's tendency to use literal translation techniques causes the low quality of translation because this technique is used in the early stages of translating and considered as the lowest technique.

3. The results of the translation by the respondents on the findings are used as decent alternative to the results of the Facebook translation. 


\section{REFERENCE}

Bogdan, R. C., \& Biklen, S. K., (1992), Qualitative Research for Education: an Introduction to Theory and Methods, Boston: Allyn \& Bacon.

Cahyadi. (2020). Kesulitan-kesulitan Dalam Penerjemahan. Available at http://ELearning.mht . Accessed on 19th of December 2020

Daniel, F. (2019). "Performance of an Automatic Translator in Translating Medical Abstracts". Heliyon, 5: 1-6

Facebook, Company info. https://about.fb.com/company-info/ Diakses 1 Maret 2021

Hatim, B., Mason, I. (2014). Discourse and the Translator. Routledge,London.

Hoed, B. H. (2006). Penerjemahan dan Kebudayaan. Jakarta: Pustaka Jaya

Khoirunida, S. (2019). "An Analysis of Grammatical Errors in The Translation Made By The Fourth Semester Students of English Education Program" in JELLT Vol 3, No 2: $114-125$

Larson, L. M. (1984). Meaning based Translation, A guide to cross language, Equivalence. Lanham: University Press of America

Machali, R. (2000). Pedoman bagi penerjemah. Jakarta: Grasindo.

Molina, L., \& Hurtado Albir, A. (2002). Translation techniques revisited: A dynamic and functionalist approach. Meta: Journal des Traducteurs/Meta: Translators' Journal, 47(4), 498-512.

Nababan, A. N., \& Sumardiono. (2012). Pengembangan Model Penilaian Kualitas Terjemahan. Jurnal Kajian Linguistik dan Sastra, 24(1) :39-57. Surakarta: Universitas Sebelas Maret.

Newmark, P. (1988). A Textbook of Translation. Shanghai Foreign Languange Education Press

Pasangka, M. (2016). The Equivalence and The Method of The Indonesian translation of English Idiom In The Subtitle Of Friday Night Lights Movie. Unpublished Undergraduate Thesis. Yogyakarta: English Letters Study Program department Of English Letters Faculty Of Letters Sanata Dharma University Yogyakarta.

Phillips, S. (2007). A Brief History of Facebook. https://www.theguardian.com/technology/2007/jul/25/media.newmedia Diakses 4 Maret 2021

Prasetyo, A. (2016). Pengertian Penelitian Deskriptif Kualitatif. https://www.linguistikid.com/2016/09/pengertian-penelitian-deskriptifkualitatif.html Diakses 25 Maret 2021

Robinson, D. (2012). Becoming a Translator - an Introduction to the Theory and Practice of Translation. Routledge, London.

Hartley, A., Tatsumi, M., Isahara, H., Kageura, K., \& Miyata, R. (2012). Readability and Translatability Judgments for "Controlled Japanese". In Proceedings of the 16th Annual conference of the European Association for Machine Translation (pp. 237244).

Taylor, C. (1998). Language to Language. Cambridge University Press, Cambridge

Vinay, J. P., \& Darbelnet, J. (2000). In Venuti, L ed. The Translation Studies Reader. Routledge. London

Yousofi, N. (2014).'Describing the Errors in the Translations of Iranian novice English Translators". International Conference on Current Trends in ELT, 1952-1958 